\title{
THE INVESTIGATION OF QUALITY INDICATORS OF INDIVIDUALIZED EDUCATION PLAN PREPARED IN PUBLIC SCHOOLS
}

\author{
Rıza Özdemirir, \\ Buket Kisaç², \\ Emre Ünlü̈, \\ Gamze Kaplan ${ }^{4}$ \\ ${ }^{1}$ Assistant Professor, \\ Zonguldak Bülent Ecevit University, \\ Turkey \\ orcid.org/0000-0001-9794-9762 \\ ${ }^{2}$ Assistant Professor, \\ Zonguldak Bülent Ecevit University, \\ Turkey \\ orcid.org/0000-0002-3311-857X \\ ${ }^{3}$ Assistant Professor, \\ Zonguldak Bülent Ecevit University, \\ Turkey \\ orcid.org/0000-0003-0795-9022 \\ ${ }^{4}$ Assistant Professor, \\ Zonguldak Bülent Ecevit University, \\ Turkey \\ orcid.org/0000-0002-3853-322X
}

\begin{abstract}
:
Individualized Education Program (IEP) is an important element in the Turkish Education system since it aims students with disabilities to get a systematic, measurable and on point education. Thus, preparation, implementation, and evaluation of the IEP play a critical role for students with disabilities, their parents, and professionals. Researchers conducted studies and provided suggestions to improve the quality of IEPs. However, in the literature, there was not any evaluation tool for the IEP. The purpose of this study is to create an evaluation tool for IEPs, and based on this tool, to measure the quality of prepared IEPs in Turkey. In this study, descriptive analysis was used. The findings demonstrated serious deficiencies in the components of IEPs. Based on that, the researchers provided suggestions to enhance the quality of IEPs.
\end{abstract}

i Correspondence: email riza.ozdemir@beun.edu.tr 
Keywords: special education, individualized education plan, rubric, students with disabilities, public schools

\section{Introduction}

Once students with disabilities (SWD) are identified as eligible to receive special education and related services, the students begin to receive necessary services for them to get an education based on the Individualized Education Plan (IEP) (Lee-Tarver, 2006). The IEP, which is considered one of the most important components of individualized education, was first introduced in the United States in 1975 with the federal law of the Individuals with Disabilities Education Act (IDEA). In a collaboration with the family and professionals, the IEP provides SWD necessary services and supports for access to the general education curriculum.

The IEP provides a road map to both special education and general education teachers in preparing an instructional plan for SWD (Kargin, 2007; Rakap, 2015; Rosas \& Winterman, 2012). This roadmap directs the education of SWD, and includes four important dimensions: a) a starting point-student's present level of performance, b) goals - measurable and observable objectives, c) support and services needed to achieve the goals, and d) measuring progress toward goal achievement- evaluating the student's performance using appropriate assessment methods (Bateman \& Herr, 2006; Lee-Tarver, 2006). With these dimensions, educators and parents could monitor students' progress and the effectiveness of the interventions in the IEP. And, if necessary, it could be improved in order to achieve its goals (Lytle \& Bordin, 2001). In addition, the IEP plays an important role in determining the instructional strategies and materials will be used to reach the target goals, guiding the delivery of special education. Considering that highquality IEPs can drive high-quality instruction. Therefore, it is crucial to design highquality IEPs to support the educational and developmental needs of SWD.

In the literature, information about how to write a qualified IEP exists (Ruble, McGrew, Dalrymple, \& Jung, 2010): a) identifying the students' needs, strengths, and interests in their present levels of performances (Erbaş, 2003), b) writing the level of performance of the students based on clear, measurable and observable terms (Kargin, 2007), c) including the IEP's functional annual goals and short-term objectives that are measurable and observable (Pretti-Frontczak \& Bricker, 2000; Rakap, 2015; SanchesFerreina, Lopes-dos-Santos \& Silveria-Maia, 2013), and d) using appropriate measurements and assessment methods to determine whether the target goals have been achieved (Kargin, 2007). However, previous studies have shown that many IEPs have not complied with proposed criteria (Ruble et al. 2010).

One dimension in the IEP are not written properly, and functionally, it is observed they are inconsistent with recommended practices (Grisham-Brown \& Hemmeter, 1998; Pretti-Frontczak \& Bricker, 2000; Yell \& Stecker, 2003). Hence, SWD exposes to ineffective instructions (Goodman \& Bond, 1993). Previous studies on IEP goals and objectives have shown a lack of clarity and data support (Shriner ve Destefano, 2003). Many IEPs lacked 
specifically functional and measurable goals (Sanches-Ferreina et al.2013; Rakap, 2015). Sanches-Ferreina et al. (2013) examined the IEP quality of 2437 Portuguese SWD and found the most missing criterion in the IEPs was measurable objective. In addition, Rakap (2015) investigated the IEP quality of 2235 Turkish students, receiving special education in early childhood, and obtained similar results to Sanches-Fereina et al. (2013). The researcher found the IEPs reviewed lacked functional goals and the most missing component in the goals was the criterion for acceptable performance. Boavida, Aguiar, McWilliam, and Pimentel (2010) also examined the quality of IEP goals written for 83 preschool students from 21 schools in Portugal. The results indicated the goals were very comprehensive, far away from functionality and measurability, and lacked the consideration of the context of natural environment and routines.

In addition to the low-quality goals, information regarding the present level of performance (PLOP) was limited and insufficient (Gartin \& Murdick, 2005). Moreover, many teaching strategies were not aligned with the IEP goals (Ruble et al. 2010). Similar to the results in the evaluation of goals, it is seen that there are significant issues and insufficiency in the planning of transition in the IEPs (Shriner \& Destefano, 2003). Grigal, Test, Beattie, and Wood (1997) found some missing elements of the transition plan to prepare SWD to lives. The IEPs constitute the most important part of the education process of the SWD and, therefore, the IDEA (1975) emphasized families are equal members of other members in the preparation of the IEP (Yell, 2012). Although family participation is mandatory in the preparation of the IEP in the legal process, research has shown that families have felt themselves outside the process and lack of encouragement for active family involvement in IEP development process (Mason, McGahee-Kovac, \& Johnson 2004; Mueller 2009; MacLeod, Causton, Radel, \& Radel, 2017).

Although studies investigated the quality of the components of IEPs in the literature, there was a lack of research on examining the quality of IEPs prepared for SWD in Turkey. Furthermore, no standards or very limited standards about how best to design and implement the IEPs were addressed (Smiley, 2007). Previous studies suggested universal quality indicators for IEPs can be determined based on similar studies that are carried out in different cultures and countries. Researchers need to examine the IEPs and identify their needs and limitations to ensure the adequate functioning of the IEP. These needs and limitations will shed light on the design of content that can guide teachers during the IEP development. For this reason, the purpose of this study is to determine the quality of IEPs prepared for SWD by the IEP evaluation tool developed by the researchers and to identify the needs in the preparation of high-quality IEP.

\section{Methods}

In this study, the researchers used descriptive analysis since descriptive analysis aimed to demonstrate the current situation of data (Karasar, 1999). The IEPs collected from public schools, and they were scored by a rubric developed by the researchers. The 
researchers investigated the descriptive results (mean, frequency, etc.) to understand the quality of IEPs.

\subsection{Data Collection}

Data were collected from the Western Black Sea region in Turkey. The researchers obtained required permissions from the district directorate of National Education. They gathered the IEPs from public schools, especially job training schools, schools that have special education and inclusive classes. The first researcher visited each school in this region, requested a copy of IEPs for SWD. In this study, the total number of IEPs used was 252.

\subsection{Rubric Development}

In this study, the researchers created a rubric in order to investigate the quality indicators of IEPs that were written by the teachers in the public schools. In the process of rubric development, the document analysis method was used since it was a method to make necessary investigation as reaching the appropriate resources based on the purpose of the study and to select the information to be utilized (Çepni, 2007). The researchers followed four steps recommended by Airasian (2001) to develop the IEP rubric: a) selecting a process or product, b) determining the performance criteria, c) deciding scale, and d) defining the best and other performances.

In order to prepare the rubric, the researchers gather information about the components and objectives of IEP development from national and international literature. Additionally, they investigated the current scales and their items to score the IEPs in the international literature. Later, the researchers clearly made operational definitions and provided explanations for each item in the rubric. They decided to use 3 points Likert scale to score the IEPs $(0=\mathrm{No}, 1=$ Somewhat, $2=Y e s)$. The rubric had 4 components: a) personal information, b) present level of performance, c) goals, and d) teaching strategies, services, accommodations, and modifications.

The rubric is supposed to be valid and reliable to measure the IEPs accurately (Ozyurek, 2015). For this reason, the researchers carefully investigated these two important aspects. In order to obtain the validity scores of the rubric, the researchers sent a rubric evaluation form to the experts in the special education field. They followed the protocol of Lawshe (1975)'s content validity ratio technique. Five experts evaluated the rubric, and the researchers reached the optimal score (.99) at the .05 significance level. Additionally, the inter-rater reliability was calculated. Of the IEPs, $30 \%$ of them were randomly selected and independently scored by the researchers. The researchers reached 89.25 points for the inter-rater reliability. This indicated this rubric had sufficient validity and reliability scores to evaluate IEPs in the public schools based on four components. 


\section{Results}

The rubric had four components to evaluate the quality indicators of Individualized Education Plans (IEP) in public schools (See Table 1). One of the components was personal information contained general information about students, parents, schools and its services. The data demonstrated students' personal information were stated usually $(\mathrm{M}=1.37 ; \mathrm{SD}=.60)$. However, the mean score decreased to .83 for parents' personal information $(S D=90)$. Given that diagnostic data are the foundation of IEP they need to be addressed all the time. However, the result demonstrated student's diagnosis information was low $(\mathrm{M}=.65 ; \mathrm{SD}=.77)$. Additionally, students' health information (medicine, doses, diet, etc.) were also low $(\mathrm{M}=.49 ; \mathrm{SD}=.83)$. Moreover, formal assessment scores $(M=.05 ; \mathrm{SD}=.22)$ and the information about the IEP team $(\mathrm{M}=.74 ; \mathrm{SD}=.85)$ had similar low scores. In sum, these findings clearly indicated that the IEPs had some missing personal information of students with disabilities.

The present level of performance (PLOP) demonstrates the students' strengths and weaknesses. This component is the first step to organize other component of the IEP. In this component, the data demonstrated IEP did not clearly show all abilities and strengths of students had $(\mathrm{M}=.65 ; \mathrm{SD}=.52)$. Also, the statements were not observable and measurable $(\mathrm{M}=.46 ; \mathrm{SD}=.55)$. Although formal and informal scores for students with disabilities are critical to enlighten the teachers and parents, the data emphasized students' formal and informal data $(\mathrm{M}=.05 ; \mathrm{SD}=.22)$ and the perceptions of test administers and teachers were almost missing $(\mathrm{M}=.23$; $\mathrm{SD}=.42)$. Finally, students' abilities and interests need to be mentioned in this component. However, the mean scores of students' interests were not stated clearly $(\mathrm{M}=.06 ; \mathrm{SD}=.23)$. Overall, the data revealed that the PLOP component had serious deficiencies.

The goals are a crucial component of the IEP since they guide teachers and professions to organize their instruction to provide the best education for SWD. In the analysis, the IEPs had, on average, 22 long-term goals (0-83), and 107 short-term goals (0403). That is, the IEP generally included long-term goals $(\mathrm{M}=1.45 ; \mathrm{SD}=.68)$ and short-term goals $(\mathrm{M}=1.57$; $\mathrm{SD}=.68)$, however, long-term statements $(\mathrm{M}=.52 ; \mathrm{SD}=.70)$ and short-term statements $(\mathrm{M}=.30 ; \mathrm{SD}=.55)$ respectively were not well written. Additionally, goals almost were not aligned with PLOP $(\mathrm{M}=.41 ; \mathrm{SD}=.50)$, assessment tools $(\mathrm{M}=.49 ; \mathrm{SD}=.70)$, and materials $(\mathrm{M}=.32 ; \mathrm{SD}=.47)$. To sum up, considering this component guides to prepare the instruction, if this component was not prepared very well, it affects other components of the IEP adversely.

Educational strategies are critical to design the instruction. The data indicated the mean score of writing educational strategies was low $(\mathrm{M}=.57 ; \mathrm{SD}=.77)$. In addition to that, accommodations and modifications are the key elements of the instruction to help students with disabilities to enhance their success. However, in this component, the IEP generally did not include the necessary accommodations and modifications for SWD $(\mathrm{M}=.06 ; \mathrm{SD}=.24)$. The multidisciplinary planning is another aspect to collaborate for IEP and students' needs. However, the data showed many IEPs had a lack of 
multidisciplinary approach $(\mathrm{M}=.18 ; \mathrm{SD}=.44)$. The aim of special education is to prepare students with disabilities to life and the IEPs guide teachers in understanding what the SWD need to do to succeed in life. However, the data demonstrated IEPs did not include transition plans $(\mathrm{M}=.05 ; \mathrm{SD}=.22)$ and inclusion plans sufficiently $(\mathrm{M}=.24 ; \mathrm{SD}=.43)$. To sum up, the data clearly emphasized that they did not provide a sufficient level of information to organize the instruction and prepare SWD to future academic and personal lives.

\section{Discussion and Conclusion}

The purpose of this study was to create an evaluation tool for IEPs and measure the quality of IEPs in Turkey based on this tool. Results were consistent with previous research that the essential components of high quality IEP were infrequently included in the reviewed IEPs (Boavida, Aguiar, McWilliam, \& Pimentel, 2010; Shinn \& Shinn, 2000). The most commonly absent components of IEPs were the present level of performance, the lack of high quality short-term and long-term goals, and the lack of accommodation and modification information to reach the goals. Although most of the IEPs contained information about personal information, some important information about this component were not addressed.

Four important conclusions can be drawn from this research study. First, the reviewed IEPs do not meet the quality criteria based on the evaluation tool, and are in need of improvement. One area of weakness was the inadequate description of present level of performance (PLOP). The PLOP demonstrates students' strengths and weaknesses and guides teachers to organize the instruction (Avcioğlu, 2015). Most of the IEPs reviewed had a few lines written in the PLOP component that was inadequate to determine appropriate goals, services, supports and accommodations. That is, there was a lack of link between the PLOP and the goals of SWD. Moreover, although PLOP component should include data from formal and informal assessments, none of the IEP reviewed had assessment information about academic and functional performance of SWD. Spears, Tollefson, and Simpson (2001) reported that both formal and informal assessment played an important role for the IEPs. The lack of assessment data raises questions as to the functionality and appropriateness of goals selected for SWD. Second area of weakness was the quality of long-term and short-term goals. Consistent with the findings of previous research (e.g., Boavida, Aguiar, McWilliam, \& Pimentel, 2010; Shinn \& Shinn, 2000) a large number of goals and objectives observed in the reviewed IEPs. The IEPs had, on average, 22 long-term goals and 107 short-term goals. Due to this large number of goals, it would be very difficult to meet all the students' needs and measure their progress in a specific timeline. Furthermore, the majority of IEP goals and objectives could not be observable and measurable. Although a few of the skills addressed in goals were observable, none of the goals and objectives included performance criterion for successful attainment of goals. These findings are consistent with the studies of SanchesFerreira et al, 2013 and Rakap (2014). Third area of weakness was the lack of information about accommodations, modifications, assistive technologies, and strategies for SWD. 
None of the accommodations (e.g., setting, time adjustment, response mode) or modifications were documented on the IEPs.

Second, the results of this study indicated the lack of consistent and systematic process for designing and implementing IEPs. Although regulations related to special education in Turkey requires teachers to prepare IEP for SWD, less guidance is provided as to how to develop high quality IEP, often resulting in inefficient education. Researchers documented the teacher perceptions about the IEP as a process and a product. Smith (1990) reported that teacher's concerns related to IEP as a process were increased workload, excessive paperwork, insufficient support and lack of adequate training. In this research study, the majority of IEPs lacked the functionality in making qualitative differences in the education of SWD. The reason why the IEP quality was generally poor may be related to the fact that general education and special education teachers had the lack of adequate training and support for addressing crucial components in an IEP. Future researchers may investigate what components of the IEP are most challenging for teachers and how to give training teachers to address these components in the IEP successfully.

Third, large number of IEP goals drew attention to issues regarding IEP implementation. Regarding the IEP as a product, researchers investigated the teachers' perceptions of IEP's effectiveness on children's learning. Rotter (2014) reported that teachers found IEP moderately useful in planning instruction and they implemented the majority of IEP objectives that had positive impact on SWD. However, the excessive amount of IEP goals found in this research implies lack of IEP implementation in schools. Teachers might have difficulty in measuring progress of over 100 goals for each student. That is, teachers may not refer to the IEP document in planning instruction. The majority of IEPs appeared to be prepared to meet only the legal obligation not educational needs. In this case, the IEPs prepared would not impact the students for whom they are written. To make qualitative differences in the education of SWD, general education and special education teachers need to use the IEP for instructional planning purposes (Rotter, 2014). Finally, the results of this study demonstrated that there is clearly a need for rubric for evaluating the IEPs in Turkey. The rubric created by the authors can be considered as an effective tool in understanding what components of IEP are in need of improvement. Since using such rubric help educators plan instruction for SWD effectively, the future research can be conducted in giving training to general and special education teacher on how to prepare IEPs that meet the quality indicators.

There are two limitations that need to be considered when interpreting the results of this study. The first limitation is the region of the study conducted. The data were collected in the Western Black Sea region in Turkey which is a small representation of this country. Future researchers should collect data from different regions of Turkey to demonstrate and generalize the effectiveness of IEP rubric. The second limitation is the validity and reliability of the rubric. The researchers obtained high scores for internal reliability and content validity. Thus, future researchers should investigate the different types of validity and reliability to improve the IEP rubric. 


\section{Recommendations}

This research study showed that the IEPs had weaknesses that might prevent to deliver effective instruction for SWD. The findings of the study conducted by Lee-Tarver (2006) revealed that teachers need more training in preparing, developing, and implementing the IEP. All of the findings support Lee-Tarver's study and recommend similar suggestions. Training program about preparing the IEP should be delivered to both general and special education teachers and the following topics would be useful to cover in the training: (a) the importance of describing personal information, (b) how to write present level of performance and what it includes, (c) how to write goals and objectives for students with disabilities, (d) how to decide what strategies, assistive technologies, accommodations, and modifications are necessary for a student with disabilities, and (e) how to make connections between components in the IEPs.

\section{Acknowledgements}

This research study is supported by Zonguldak Bülent Ecevit University Scientific Research Project Grant (Grant number: 2018-53326746-01).

\section{References}

Airasian, P. W. (2001). Classroom Assesment, Mc Graw Hill, Boston College.

Avcioglu, H. (2011). Zihin engelliler sinif ögretmenlerinin bireysellestirilmis egitim programi (BEP) hazirlamaya iliskin görüsleri. Ankara Üniversitesi Ĕ̆itim Bilimleri Fakültesi Özel Ĕ̆itim Dergisi, 12(1), 39-56.

Bateman, B. D., \& Herr, C. M. (2006). Writing measurable IEP goals and objectives. Verona, WI: IEP Resources.

C,epni, S. (2007). Araştırma ve Proje Çalışmalarına Giriş. Trabzon: Celepler Matbaacılık.

Erbaş, D. (2003). Varolan performans düzeyinin belirlengesi ve yazılması. O. Gürsel (Ed.). Bireyselleştirilmiş eğitim programlarının geliştirilmesi (69-80). Eskişehir: Anadolu Üniversitesi Yayınları.

Gartin, B., C. \& Murdick, N. L. (2005). IDEA 2004: The IEP. Remedial and Special Education, 26,6, 327-331.

Goodman, J., \& Bond, L. (1993). The individualized education program: A retrospective critique. Journal of Special Education, 26, 408-422.

Grisham-Brown, J. F., \& Hemmeter, M. L. (1998). Writing IEP goals and objectives: Reflecting an activity-based approach to instruction for young children with disabilities. Young Exceptional Children, 1(3), 2-10.

Kargın, T. (2007). Eğitsel değerlendirme ve bireyselleştirilmiş eğitim programı hazırlama süreci. Ankara Üniversitesi Eğitim Bilimleri Fakültesi Özel Ĕ̆gitim Dergisi, 8(1), 01-16. 
Rakap, S. (2015). Quality of individualised education programme goals and objectives for preschool children with disabilities, European Journal of Special Needs Education, 30(2), 173-186, DOI: 10.1080/08856257.2014.986909

Lee-Tarver, A. (2006). Are individualized education plans a good thing? A survey of teachers' perceptions of the utility of IEPs in regular education settings. Journal of Instructional Psychology, 33(4), 263-272.

Lytle, R. K., \& Bordin, J. (2001). Enhancing the IEP team strategies for parents and professionals. Teaching Exceptional Children, 33(5), 40-44.

MacLeod, K., Causton, J. N., Radel, M., \& Radel, P. (2017). Rethinking the Individualized Education Plan process: voices from the other side of the table. Disability $\mathcal{E}$ Society, 32(3), 381-400.

Mason, C. Y., M. McGahee-Kovac, and L. Johnson (2004). How to help students lead their IEP meetings. Teaching Exceptional Children 36 (3), 18-24.

Mueller, T. G. (2009). IEP facilitation. Teaching Exceptional Children 41 (3), 60-67.

Öztürk, C. Ç., \& Eratay, E. (2010). Eğitim uygulama okuluna devam eden zihin engelli öğrencilerin öğretmenlerinin Bireyselleştirilmiş Eğitim Programı hakkında görüşlerinin belirlenmesi. Abant İzet Baysal Üniversitesi Dergisi, 10(2), 146-159.

Pretti-Frontczak, K. \& Bricker, D. (2000). Enhancing the quality of individualized education goal and objectives. Journal of Early Intervention, 23(2), 92-105

Rosas, C. E., \& Winterman, K. G. (2012). The use of a rubric as a tool to guide pre-service teachers in the development of IEPs. Journal of the American Academy of Special Education Professionals, 136-147.

Rotter, K. (2014). IEP use by general and special education teachers. SAGE Open 4(2), 1-8.

Ruble, L. A., McGrew, J., Dalrymple, N. \& Jung, L. A. (2010). Examining the quality of IEPs for young children with autism. Journal of Autism and Developmental Disabilities, 40(12), 1459-1470.

Sanches-Ferreira, M., Lopes-Dos-Santos, P., Alves, S., Santos, M, \& Silveira-Maia M. (2013). How individualized are the individualized education programs (IEPs) : an analysis of contents and quality of the IEP goals. European Journal of Special Needs Education, 28(4), 507-520.

Vuran, S. (2007). Bireyselleştirilmiş eğitim programları (BEP). Gürsel, O. (Ed.). Bireyselleştirilmiş eğitim programlarının geliştirilmesi. Eskişehir: Anadolu Üniversitesi Yayınları.

Shriner, J. G., \& Destefano, L. (2003). Participation and accommodation in state assessment: The role of individualized education programs. Exceptional Children, 69(2), 147-161.

Smiley, A. D. (2007). Power, families of color, and special education: A qualitative examination of discourse between families and professionals in an urban setting. (Doctoral Dissertation). Available from ProQuest Dissertations and Theses database. (UMI No. 3255509).

Smith, S. W. (1990). Individualized education programs in special education: From intent to acquiescence. Exceptional Children, 57, 6-14. 
Yell, M. L., \& Stecker, P. M. (2003). Developing legally correct and educational meaningful IEPs using curriculum-based measurement. Assessment for Effective Intervention, 28, 73-88.

Yell, M. L. (2012). The law in special education. (3rd Ed.) Boston, MA: Pearson. 


\section{Appendix}

\section{Figures and Tables}

Table 1: The descriptive results of rubric items

\begin{tabular}{|c|c|c|}
\hline & $\mathbf{M}$ & SD \\
\hline A1. Student's name, surname, and age are clearly written in the IEP. & 1.37 & .60 \\
\hline $\begin{array}{l}\text { A2. Student parent's name, surname, contact information, and address are clearly written } \\
\text { in the IEP. }\end{array}$ & .83 & .89 \\
\hline $\begin{array}{l}\text { A3. Student's type of disability, degree of disability (e.g., mild, moderate, severe), which } \\
\text { diagnostic tool used and who administered the test are clearly stated in the IEP. }\end{array}$ & .65 & .76 \\
\hline $\begin{array}{l}\text { A4. Student's current school he/she attends and special education services he/she receives } \\
\text { (e.g., speech therapy, occupational therapy) are stated. }\end{array}$ & .57 & .84 \\
\hline $\begin{array}{l}\text { A5. Medical information, if any the student uses drug, prosthesis devices (e.g., hearing } \\
\text { aid) or a special diet, is provided in the IEP. }\end{array}$ & .49 & .82 \\
\hline $\begin{array}{l}\text { A6. The assessment tools used in the evaluation of the student and the results obtained } \\
\text { from these tools are written in the student's IEP. }\end{array}$ & .05 & .22 \\
\hline $\begin{array}{l}\text { A7. The names and titles of all the team members involved in the development of the IEP } \\
\text { and their duties and responsibilities in the IEP were clearly written. }\end{array}$ & .74 & .85 \\
\hline $\begin{array}{l}\text { B8. The level of performance of the student is written for all developmental areas } \\
\text { (cognitive, social, emotional, motor, language and communication). }\end{array}$ & .65 & .52 \\
\hline $\begin{array}{l}\text { B9. The tests performed in the formal evaluation process and the scores received by the } \\
\text { student were stated and interpreted. }\end{array}$ & .05 & .22 \\
\hline $\begin{array}{l}\text { B10. Student's strengths in developmental areas-cognitive, social, emotional, motor and } \\
\text { communication-are stated in the IEP. }\end{array}$ & .42 & .53 \\
\hline B11. Student's interests and reinforces (e.g., toys, activities,) are specified. & .06 & .23 \\
\hline $\begin{array}{l}\text { B12. In the formal and informal evaluation process, the general opinions of the experts } \\
\text { about the student are stated. }\end{array}$ & .23 & .42 \\
\hline $\begin{array}{l}\text { B13. Performance level statements are written in a clear, comprehensible, observable and } \\
\text { measurable manner that shows the skills the student can make and develop from the } \\
\text { areas of cognitive, social, motor, language and communication. }\end{array}$ & .46 & .55 \\
\hline C14. Annual goals expected to be accomplished by the student are described. & 1.45 & .68 \\
\hline $\begin{array}{l}\text { C15. Annual goals are operationally defined (i.e., observable, measurable, and objective } \\
\text { definition of the goal). }\end{array}$ & .52 & .69 \\
\hline C16. Short-term objectives expected to be accomplished by the student are described. & 1.57 & .63 \\
\hline $\begin{array}{l}\text { C17. Short-term objectives are operationally defined and written in a manner that has four } \\
\text { components (individual, clearly defined behavior, condition and performance criteria). }\end{array}$ & .30 & .55 \\
\hline C18. Goals are written in a manner that links them with the student's needs and strengths. & .39 & .49 \\
\hline $\begin{array}{l}\text { C19. Materials and teaching methods to be used, timeline for goal attainment and in } \\
\text { which environment this goal will be achieved are described. }\end{array}$ & .53 & .60 \\
\hline $\begin{array}{l}\text { C20. How often the performance of the student will be evaluated for all targeted goals are } \\
\text { written. }\end{array}$ & .18 & .38 \\
\hline $\begin{array}{l}\text { C21. Tools to be used in the evaluation of student performance for each goal are } \\
\text { described. }\end{array}$ & .49 & .70 \\
\hline C22. The assessment tools selected are sufficient and appropriate to measure the goals. & .34 & .53 \\
\hline $\begin{array}{l}\text { C23. Appropriate instruction, materials and assessment tools are chosen for the goals } \\
\text { expected to be achieved. }\end{array}$ & .32 & .47 \\
\hline $\begin{array}{l}\text { C24. Targeted annual goals are consistent with the student's present levels of } \\
\text { performance. }\end{array}$ & .41 & .49 \\
\hline
\end{tabular}




\begin{tabular}{|l|c|c|}
\hline \hline D25. Instructional strategies to be used for each goal are described. & .57 & .76 \\
\hline $\begin{array}{l}\text { D26. The required adaptations and changes to make the student reach the desired goal are } \\
\text { stated. }\end{array}$ & .06 & .23 \\
\hline $\begin{array}{l}\text { D27. In order to measure the performance of the student accurately and reliably, the } \\
\text { necessary adaptations and changes in the evaluation process are described. }\end{array}$ & .05 & .22 \\
\hline $\begin{array}{l}\text { D28 For the student to reach the desired target behavior, the necessary adaptations and } \\
\text { changes for the material are described. }\end{array}$ & .06 & .23 \\
\hline $\begin{array}{l}\text { D29. An education planning was made that would allow interdisciplinary (e.g., } \\
\text { occupational therapist, speech therapist) work for the skills that were intended to be } \\
\text { provided to the student. }\end{array}$ & .18 & .43 \\
\hline $\begin{array}{l}\text { D30. The inclusion activities that will ensure the social and academic development of the } \\
\text { student are included. }\end{array}$ & .24 & .43 \\
\hline $\begin{array}{l}\text { D31. Transition services - information on additional services and support (e.g., speech } \\
\text { therapy, physiotherapy, group training, individual training, transport, etc.)-necessary for } \\
\text { the student transition from one program to another program (e.g., from preschool to } \\
\text { primary education program) is provided. }\end{array}$ & .05 & .22 \\
\hline $\begin{array}{l}\text { D32. Information about special education services to be provided-projected beginning } \\
\text { date, frequency, location, and duration of the services-is described. }\end{array}$ & .16 & .36 \\
\hline $\begin{array}{l}\text { D33. In order to help student gain academic and communication skills, it is stated which } \\
\text { tools should be used if assistive technology is deemed necessary. }\end{array}$ & .06 & .23 \\
\hline D34. Where the training will be given (e.g., inclusion classroom) is indicated. & .05 & .22 \\
\hline $\begin{array}{l}\text { D35. The person (s) responsible for the training (e.g., special education teacher, class } \\
\text { teacher, etc.) is indicated. }\end{array}$ & .45 & .73 \\
\hline
\end{tabular}

Note: $A=$ Personal information, $B=$ Present level of performance, $C=$ Goals, and $D=$ Instructional strategies, adaptations, and related services. 
Rıza Özdemir, Buket Kısaç, Emre Ünlü, Gamze Kaplan

THE INVESTIGATION OF QUALITY INDICATORS OF INDIVIDUALIZED

EDUCATION PLAN PREPARED IN PUBLIC SCHOOLS

Creative Commons licensing terms

Authors will retain the copyright of their published articles agreeing that a Creative Commons Attribution 4.0 International License (CC BY 4.0 ) terms will be applied to their work. Under the terms of this license, no permission is required from the author(s) or publisher for members of the community to copy, distribute, transmit or adapt the article content, providing a proper, prominent and unambiguous attribution to the authors in a manner that makes clear that the materials are being reused under permission of a Creative Commons License. Views, opinions and conclusions expressed in this research article are views, opinions and conclusions of the author(s). Open Access Publishing Group and European Journal of Special Education Research shall not be responsible or answerable for any loss, damage or liability caused in relation to/arising out of conflict of interests, copyright violations and inappropriate or inaccurate use of any kind content related or integrated on the research work. All the published works are meeting the Open Access Publishing requirements and can be freely accessed, shared, modified, distributed and used in educational, commercial and non-commercial purposes under a Creative Commons Attribution 4.0 International License (CC BY 4.0). 